\title{
CORRESPONDENCE.
}

\section{A Rectification.}

3, Via San Francesco Poverino, Florence. January 9, 1902.

My dear Professor, -I have recently received a letter from General Houtum Sehindler in Tehran, from which it appears that, quite unintentionally, I have misstated his views in my recent paper (J.R.A.S. for April, 1901) on "The Cities of Kirman." I therefore hasten to set the matter right. In regard to the site of Sījān (p. 282 of last year's volume) I have misunderstood General Schindler in supposing that he had identified this place with the modern Sa'īāanād; on the contrary, General Schindler is of opinion that this, the older capital, probably stood in the Māshizz plain, which is considerably to the eastward of Sa'îabād. In the second place, in connection with the etymology of the name Bardasir (note 1 to p. 283), General Schindler disclaims any reliance on the statements of the Persian dictionary called Farhang-i-Anjumān Arā, which he knew to be misleading and incorrect.-Believe me to be, yours most truly,

G. Le Strange.

\section{The term Sahampati.}

SIR,-In the course of Dr. Anesaki's interesting letter on the $\bar{A}$ gamas in the J.R.A.S. for 1901 , p. 899 , he gives the 